tion of the central nervous system or be direct evidence of active infection of the central nervous system. To solve the issue of active infection of the brain in early infection with HTLV-III virus or viral antigens must be shown to be present in the cerebrospinal fluid. Levy et al reported that active replication of HTLV-III occurred within the central nervous system before clinical signs of AIDS or AIDS encephalopathy developed. ${ }^{3}$ The inthrathecally produced antibody to HTLV-III observed in these patients with syphilis indicates that HTLV-III may enter the central nervous system early in infection.

We thank R V W van Eyk (Rijks Instituut Volkszondheid en Milieuhygiene) for performing the Treponema pallidum haemagglutination assays and Riet de Krieger-Reumkens for preparing the manuscript. This study is partly funded by the Praeventiefonds.

\section{References}

1 Epstein LG, Sharer LR, Joshi VV, Fojas MM, Koenings-berger MR, Oleske JM. Progressive encephalopathy in children with acquired immune deficiency syndrome. Ann Neurol 1985;17: 488-96.
2 Shaw GM, Harper ME, Hahn BH, et al. HTLV-III infection in brains of children and adults with AIDS encephalopathy. Science 1985;227:177-82.

3 Levy JA, Shimabukuro J, Hollander H, Mills J, Kaminsky L. Isolation of AIDS-associated retrovirus from cerebrospinal fluid and brain of patients with neurological symptoms. Lance 1985; ii:580-6.

4 Resnick L, diMarzo-Veronese F, Schupbach J, et al. Intra blood-brain-barrier synthesis of HTLV-III-specific IgG in patients with neurologic symptoms associated with AIDS or AIDS related complex. N Engl f Med 1985;313:1498-504

5 Martinez P, Carcia-Saiz A, Rapun JL, Echevarria JM. Intrathecal synthesis of IgG antibodies to varicellazoster in two cases of acute aseptic meningitis syndrome with mucocutaneous lesions. $\mathcal{f}$ Med Virol 1985;16:201-9.

6 Klapper PE Laing It Longson M. Rapid non-invasive diagnosis of herpes encephalisis. Lance $1981 ;$ ii:607-9.

Lefvert AK, Link H. IgG production within the central nervous system: a critical review of proposed formulae. Ann Neurol 1985;17:13-20.

8 Tibbling G, Link H, Ohman S. Principles of albumin and IgG analyses in neurological disorders. I. Establishment of reference values. Scand f Clin Lab Invest 1977;37:385-90.

9 Hische EAH, van Meegen MT, van der Helm HJ. More precise determination of the cerebrospinal fluid IgG index. Clin Chem 1985;31:1417.

10 Van der Helm HJ, Hische EAH, van Walbeek HK. Monoclonal immunoglobulins demonstrable in cerebrospinal fluid by use of cellulose acetate electrophoresis. Clin Chem 1980;26:1917-8.

11 Griffin DE, Narayan O, Bulowski JF, Adams RJ, Cohen SR. The cerebrospinal fluid in visna, slow viral disease of sheep. Ann Neurol 1978:4:212-8.

12 Petursson G, Nathanson N, Georgsson, Panitch H, Palsson PA. Pathogenesis of visna. I. Sequential virological, serological and pathologic studies. Lab Invest 1976;35:402-12.

(Accepted l April 1986)

\title{
Biological markers of alcohol intake among 4796 subjects injured in accidents
}

\author{
L PAPOZ, J WEILL, J L'HOSTE, Y CHICH, C GOT, Y GOEHRS
}

\begin{abstract}
An epidemiological survey was carried out in France in 1982-3 to study the proportions of occasional and chronic drinkers among people injured in accidents of all kinds. The characteristics of 4796 victims recruited in the emergency units of 21 hospitals were recorded. Systematic blood sampling was performed to determine the blood alcohol concentration and two markers of chronic alcohol consumption- $\gamma$-glutamyltransferase activity and mean corpuscular volume. Alcohol was present in the blood of $35 \%$ of the injured people, with concentrations exceeding $17.4 \mathrm{mmol} / \mathrm{l}$ $(0.8 \mathrm{~g} / 1)$ in one man out of four and in one woman out of 10 . $\gamma$-Glutamyltransferase values and mean corpuscular volume were also much higher than in a reference population of healthy subjects, indicating that most of the intoxicated subjects were probably chronic drinkers. This was confirmed by a discriminant analysis which showed an overall proportion of $30 \%$ of chronic drinkers among casualties.
\end{abstract}

In France, therefore, the policy for preventing accidents should focus on chronic as much as on occasional drinking.

National Institute of Health and Medical Research (INSERM), Villejuif, France

L PAPOZ, PHD, research fellow

University of Tours, Tours, France

J WEILL, MD, professor of biochemistry

National Institute of Research on Transports and Safety, Paris, France J L'HOSTE, PHD, director

Y CHICH, PHD, psychologist

Hôpital R Poincaré, Garches, France

C GOT, MD, professor of anatomy and pathology

National Health Insurance Company, Paris, France

Y GOEHRS, PHD, director of accident prevention services

Correspondence and requests for reprints to: Dr Papoz, INSERM Unité 21 16 Avenue Paul Vaillant Couturier, 94807 Villejuif Cedex, France.

\section{Introduction}

Traffic accidents are known to be strongly associated with alcoholic intoxication, so many countries enforce a legal limit on the blood alcohol concentration of drivers. Epidemiological studies have so far been mostly based on blood or breath alcohol values measured at the time of the accident. ${ }^{1-6}$ Only a few authors have tried to evaluate to what extent the presence of alcohol in the blood might be related to chronic heavy drinking (Pikkarainen J, Pentilla A, 8th International Conference on Alcohol, Drugs, and Traffic Safety, Stockholm 1980)..$^{7.9}$

Nevertheless, the knowledge of this relation, if any, might be of paramount importance in optimising preventive action against accidents. This is particularly true in France, where alcohol consumption remains one of the highest in the world ${ }^{10}$ and where traffic accidents are the major cause of premature death, leading to about 11000 deaths each year. ${ }^{11}$ Furthermore, alcohol consumption is likely to play a part in other kinds of accidents occurring at home, at work, or during leisure or sport activities.

To tackle these problems a nationwide epidemiological survey was started in 1982, at the Prime Minister's request, to assess the proportions of occasional and chronic heavy drinkers concerned in accidents. It was decided to measure systematically, in addition to the blood alcohol concentration, the $\gamma$-glutamyltransferase activity and the mean corpuscular volume, both of which, alone ${ }^{1213}$ and in combination, ${ }^{14}$ correlate reasonably well with usual alcohol intake.

\section{Population and methods}

\section{POPULATION}

The subjects were recruited from October 1982 to March 1983 in the emergency units of 21 hospitals, two in Paris and the other 19 in towns all over France. In each centre the study schedule was planned so that each day of the week and each hour of the day were equally represented.

The criteria for inclusion were: $(a)$ that the subject presented, with or without apparent injury, after an accident of any kind, including traffic accidents, accidents at work, in the home, or during leisure or sporting 
activities, and fights; $(b)$ that the subject or family member gave consent for blood sampling; (c) that the blood was sampled within three hours of accident; and $(d)$ that the subject was aged 15 or over.

In the case of car accidents any passengers were assumed not to have been responsible and were excluded from the study.

\section{DATA COLLECTION}

The main characteristics of the subject (sex, age, and socioeconomic status) and circumstances of the accident (time, place, kind, vehicle, and severity) were obtained in an interview performed by a senior medical student assigned to the study and specially trained over several sessions.

\section{LABORATORY MEASUREMENTS}

The blood alcohol concentration and mean corpuscular volume were determined locally by routine methods. Measurement of $\gamma$-glutamyltransferase activity was performed centrally under the supervision of one of us (JW) and estimated at $37^{\circ} \mathrm{C}$ on a reaction rate automated analyser using a method derived from that of Szasz. ${ }^{15}$

\section{STATISTICAL ANALYSIS}

Data processing, including strict control of the values, was conducted by the National Road Safety Agency and the National Institute for Health and Medical Research.

Classic methods were used for comparisons ( $\chi^{2}$ test and Student's $t$ test) and correlations (Pearson's $r$ coefficient). Logarithmic transformation was applied to the individual $\gamma$-glutamyltransferase values before calculation.

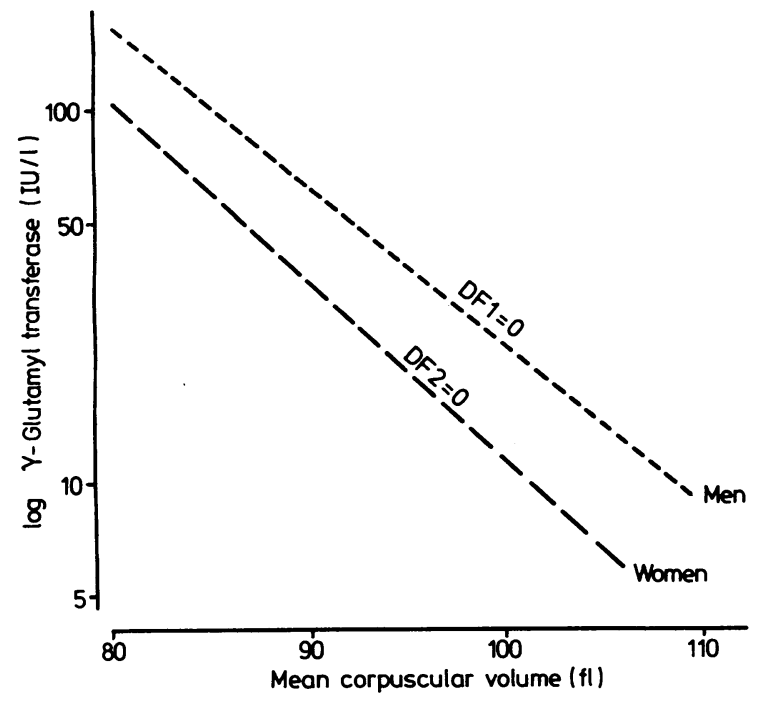

Classification of subjects according to their mean corpuscular volume and $\gamma$-glutamyltransferase values. Men: $\mathrm{DF} 1=\log \gamma$-glutamyltransferase +0.043 mean corpuscular volume $-5 \cdot 67$. Women: DF2 $=\log \gamma$ glutamyltransferase +0.048 mean corpuscular volume $-5 \cdot 85$. Light drinkers were those falling below and heavy drinkers those falling above the corresponding straight lines $(\mathrm{DF} 1=0$ for men or $\mathrm{DF} 2=0$ for women).

The subjects were classified as "chronic heavy drinkers" on the sole basis of their $\gamma$-glutamyltransferase activities and mean corpuscular volume according to the discriminant functions established for both sexes in another study. ${ }^{14}$ This study included 995 healthy adults (604 men and 391 women), who were taken as a reference population for the present study. In addition to giving blood samples for $\gamma$-glutamyltransferase and mean corpuscular volume determination these 995 adults had been systematically interviewed on their usual dietary habits, including alcohol consumption. Those men who usually drank more than $80 \mathrm{~g}$ of pure alcohol daily and those women who drank more than $30 \mathrm{~g}$ were considered as heavy drinkers and all others as light drinkers. The equations of the corresponding discriminant functions given in the figure (DF1 and DF2) were estimated on the basis of this classification. These functions were linear combinations of $\gamma$-glutamyltrans- ferase activities and mean corpuscular volume, in which the coefficients were calculated to maximise the difference between heavy and light drinkers. The constant term was adjusted so that the specificity of the method would be theoretically $90 \%$. Heavy drinkers were then defined by a positive score and light drinkers by a negative one. Finally, each equation resulted in a straight line, allowing a simple graphic method for the individual allocation of the casualties (figure). Acute intoxication was assessed on the basis of a blood alcohol concentration exceeding $17 \cdot 4 \mathrm{mmol} / 1(0.8 \mathrm{~g} / \mathrm{l})$, which is the legal upper limit for drivers in France. Age was not taken into account since its coefficient was not significant in the reference population, either for men (mean age (SD) $41 \cdot 8(12 \cdot 0)$ years, range $19-75)$ or for women $(39 \cdot 8(13 \cdot 1)$ years, range $18-76)$.

\section{Results}

\section{CHARACTERISTICS}

A total of 4796 subjects of both sexes were included in the study. The baseline characteristics are given in table I and compared with those of the total population according to the 1982 French national census. ${ }^{16}$ Compared with the national data the sample of casualties included an excess of men $(72 \%)$ and of young active people (mean age $34 \cdot 5$ in men and $42 \cdot 2$ in women). Traffic accidents accounted for about four cases out of 10 in both men and women. Not surprisingly, men were more often the victims of occupational accidents $(26 \%)$, whereas women were more often victims of accidents occurring at home (35\%). Overall, about four subjects out of 10 remained in hospital after their admission to the emergency unit.

TABLE I-Characteristics of injured subjects compared with those of total French population

\begin{tabular}{|c|c|c|c|c|}
\hline & \multicolumn{2}{|c|}{ Men } & \multicolumn{2}{|c|}{ Women } \\
\hline & $\begin{array}{c}\text { Casualties } \\
(\mathbf{n}=3427) \\
\%(\mathrm{No})\end{array}$ & $\begin{array}{c}\text { French } \\
\text { population } \\
\%\end{array}$ & $\begin{array}{c}\text { Casualties } \\
(\mathbf{n}=1369) \\
\%(\mathrm{No})\end{array}$ & $\begin{array}{c}\text { French } \\
\text { population } \\
\%\end{array}$ \\
\hline $\begin{array}{l}\text { Age: } \\
15-24 \\
25-34 \\
35-44 \\
45-54 \\
\geqslant 55\end{array}$ & $\begin{array}{lc}32 & (1081) \\
28 & (952) \\
18 & (602) \\
12 & (412) \\
11 & (380)\end{array}$ & $\begin{array}{l}20 \\
21 \\
16 \\
16 \\
27\end{array}$ & $\begin{array}{ll}25 & (346) \\
22 & (310) \\
13 & (175) \\
12 & (156) \\
28 & (378)\end{array}$ & $\begin{array}{l}18 \\
20 \\
14 \\
14 \\
34\end{array}$ \\
\hline $\begin{array}{l}\text { Socioeconomic status: } \\
\text { Farmers } \\
\text { Managers } \\
\text { Middle managers } \\
\text { Employees } \\
\text { Workers } \\
\text { Army, art, police } \\
\text { Students, retired, } \\
\text { non-workers } \\
\text { Unemployed } \\
\text { Professional drivers }\end{array}$ & $\begin{array}{rr}2 \cdot 4 & (80) \\
6 \cdot 7 & (227) \\
6 \cdot 7 & (228) \\
17 \cdot 3 & (589) \\
33.6 & (1145) \\
2 \cdot 4 & (82) \\
& \\
18.8 & (643) \\
7 \cdot 3 & (249) \\
4 \cdot 8 & (163)\end{array}$ & $\begin{array}{r}1 \cdot 2 \\
11 \cdot 7 \\
8 \cdot 5 \\
5 \cdot 8 \\
20 \cdot 2 \\
1 \cdot 6 \\
\\
44 \cdot 8 \\
4 \cdot 2 \\
2 \cdot 0\end{array}$ & $\begin{array}{rr}10 \cdot 0 & (14) \\
6 \cdot 1 & (83) \\
3 \cdot 5 & (48) \\
26 \cdot 2 & (357) \\
5 \cdot 3 & (72) \\
0.6 & (8) \\
& \\
52 \cdot 1 & (709) \\
4 \cdot 7 & (63) \\
0.6 & (8)\end{array}$ & $\begin{array}{r}0 \cdot 5 \\
5 \cdot 7 \\
4 \cdot 2 \\
17 \cdot 2 \\
5 \cdot 4 \\
0 \cdot 2 \\
\\
61 \cdot 9 \\
4 \cdot 9 \\
<0 \cdot 1\end{array}$ \\
\hline $\begin{array}{c}\text { Accident: } \\
\text { Traffic } \\
\text { Work } \\
\text { Home } \\
\text { Sport } \\
\text { Fight }\end{array}$ & $\begin{array}{rr}38 & (1313) \\
26 & (882) \\
17 & (580) \\
7 & (230) \\
12 & (420)\end{array}$ & & $\begin{array}{r}43(578) \\
8(111) \\
35(483) \\
5(70) \\
9(123)\end{array}$ & \\
\hline $\begin{array}{l}\text { Admitted to hospital after } \\
\text { accident }\end{array}$ & $37(1281)$ & & $42(573)$ & \\
\hline
\end{tabular}

\section{BIOLOGICAL MARKERS}

The distribution of $\gamma$-glutamyltransferase and mean corpuscular volume values showed considerable differences between injured subjects and the reference population (table II). The mean values as well as the proportions of subjects with a $\gamma$-glutamyltransferase value higher than $40 \mathrm{IU} / 1$ or mean corpuscular volume higher than $97 \mathrm{fl}$ were all significantly higher among injured subjects, especially among men. A blood alcohol concentration greater than $2 \cdot 2 \mathrm{mmol} / \mathrm{l}(0 \cdot 1 \mathrm{~g} / \mathrm{l})$ was found in $41 \%$ of the men and in $25 \%$ it was over $17.4 \mathrm{mmol} / 1(0.8 \mathrm{~g} / \mathrm{l})$. In both sexes alcoholic intoxication was commonly associated with fights-more often than with traffic accidents in men and more often than with domestic accidents in women (table III).

Significant correlations were found between each of $\gamma$-glutamyltransferase and mean corpuscular volume values and the blood alcohol concentration. Blood alcohol concentration seemed poorly related to age, but this lack of correlation was probably due to the non-linearity of the relation: a detailed analysis showed that blood alcohol concentration increased with age up to 45 , then remained more or less stable up to 65 and decreased afterwards. 
TABLE II-Biological results of the injured subjects compared with reference population

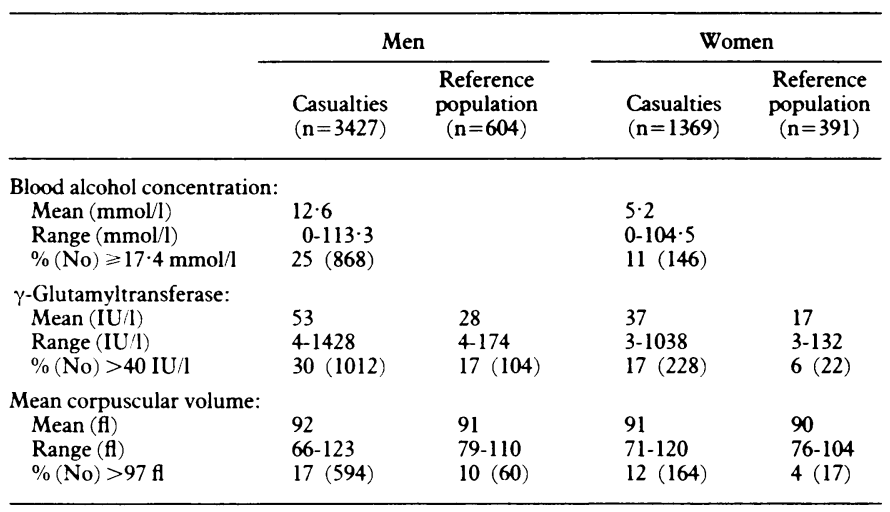

Conversion: SI to traditional units_-Blood alcohol: $1 \mathrm{mmol} / \mathrm{l} \approx 0.046 \mathrm{~g} / \mathrm{l}$

TABLE III-Biological results in injured subjects according to type of accident

\begin{tabular}{|c|c|c|c|}
\hline $\begin{array}{l}\text { Type of accidents } \\
\text { (and No of } \\
\text { subjects) }\end{array}$ & $\begin{array}{l}\text { Blood alcohol } \\
\geqslant 17 \cdot 4 \mathrm{mmol} / 1 \\
\%(\mathrm{No})\end{array}$ & $\begin{array}{c}\gamma \text {-Glutamyltransferase } \\
>40 \mathrm{IU} / 1 \\
\%(\mathrm{No})\end{array}$ & $\begin{array}{c}\text { Mean corpuscular } \\
\text { volume } \\
>97 \mathrm{fl} \\
\%(\mathrm{No})\end{array}$ \\
\hline $\begin{array}{l}\text { Men: } \\
\text { Traffic }(1313) \\
\text { Work }(882) \\
\text { Home }(580) \\
\text { Sport }(230) \\
\text { Fight }(420)\end{array}$ & $\begin{array}{c}(n=868) \\
30.9(406) \\
8.3(73) \\
25.0(145) \\
3.0(7) \\
56.4(237)\end{array}$ & $\begin{array}{l}(\mathrm{n}=1012) \\
30 \cdot 1(395) \\
27 \cdot 0(238) \\
35 \cdot 3(205) \\
12 \cdot 6 \quad(29) \\
34 \cdot 5(145)\end{array}$ & $\begin{array}{c}(n=594) \\
18 \cdot 1(237) \\
13 \cdot 0(115) \\
22 \cdot 4(130) \\
4 \cdot 8(11) \\
24 \cdot 0(101)\end{array}$ \\
\hline $\begin{array}{l}\text { Women: } \\
\text { Traffic }(578) \\
\text { Work }(111) \\
\text { Home }(483) \\
\text { Sport }(70) \\
\text { Fight }(123)\end{array}$ & \begin{tabular}{rr}
\multicolumn{2}{c}{$(n=146)$} \\
$8 \cdot 5$ & $(49)$ \\
$0 \cdot 9$ & $(1)$ \\
$12 \cdot 4$ & $(60)$ \\
1.4 & $(1)$ \\
$28 \cdot 5$ & $(35)$
\end{tabular} & \begin{tabular}{rr}
\multicolumn{2}{c}{$(n=228)$} \\
$14 \cdot 5$ & $(84)$ \\
$8 \cdot 1$ & $(9)$ \\
$22 \cdot 0$ & $(106)$ \\
$4 \cdot 3$ & $(3)$ \\
$21 \cdot 1$ & $(26)$
\end{tabular} & \begin{tabular}{rr}
\multicolumn{2}{c}{$(\mathrm{n}=164)$} \\
$9 \cdot 2$ & $(53)$ \\
$4 \cdot 5$ & $(5)$ \\
$16 \cdot 8$ & $(81)$ \\
$1 \cdot 4$ & $(1)$ \\
$19 \cdot 5$ & $(24)$
\end{tabular} \\
\hline
\end{tabular}

Conversion: SI to traditional units-Blood alcohol: $1 \mathrm{mmol} / \mathrm{l} \approx 0 \cdot 046 \mathrm{~g} / 1$.

\section{CLASSIFICATION OF THE SUBJECTS}

Among men $27 \%$ of the accident victims were classified as chronic heavy drinkers according to equation DF1 (positive score). This meant that their $\gamma$-glutamyltransferase and mean corpuscular volume values were at least equal to those of the men in the reference population who reported a daily consumption of $80 \mathrm{~g}$ or more of pure alcohol. For women the figure was $32 \%$, according to equation DF2, which referred to a limit of $30 \mathrm{~g}$ of pure alcohol (table IV)

It was then possible to estimate the proportion of occasional drinkers defined by a blood alcohol concentration greater than $17.4 \mathrm{mmol} / 1(0.8 \mathrm{~g} / \mathrm{l})$ associated with a negative DF1 (or DF2) score. Overall $11 \%(390)$ of men and $2 \%$ (32) of women fell into this category. All subjects not recognised as chronic or occasional drinkers on these criteria were classified as "nondrinkers." The breakdown by kind of accident showed that occasional

TABLE IV-Classification of the injured subjects according to their $\gamma$-glutamyltransferase and mean corpuscular volume values using discriminant functions assessed in reference population

\begin{tabular}{|c|c|c|c|c|}
\hline & \multicolumn{2}{|c|}{ Casualties } & \multicolumn{2}{|c|}{ Reference population } \\
\hline & $\underset{(n=3427)}{\text { Men }}$ & $\begin{array}{l}\text { Women } \\
(n=1369)\end{array}$ & $\underset{(n=604)}{\text { Men }}$ & $\begin{array}{l}\text { Women } \\
(\mathrm{n}=391)\end{array}$ \\
\hline $\begin{array}{l}\text { Alcohol consumption: } \\
\text { Mean (g pure alcohol/day) } \\
\%(\mathrm{No})>80 \mathrm{~g} / \text { day } \\
\%(\mathrm{No})>30 \mathrm{~g} / \text { day }\end{array}$ & \multicolumn{2}{|c|}{$\begin{array}{l}\text { Unknown } \\
\text { Unknown } \\
\text { Unknown }\end{array}$} & $\begin{array}{l}43 \\
11(64)\end{array}$ & $\begin{array}{l}13 \\
14(56)\end{array}$ \\
\hline \multicolumn{4}{|c|}{ Classification according to discriminant functions: } & \\
\hline $\begin{array}{l}\text { Chronic drinkers (DF2>0) } \\
\text { Specificity (\%) } \\
\text { Sensitivity (\%)† }\end{array}$ & \multicolumn{2}{|c|}{$\begin{array}{l}\text { Unknown } \\
\text { Unknown }\end{array}$} & $\begin{array}{l}90 \\
33\end{array}$ & $\begin{array}{l}13(51) \\
90 \\
28\end{array}$ \\
\hline
\end{tabular}

* Percentage of subjects not classified as chronic drinkers among those declaring less than $80 \mathrm{~g} /$ day (or $30 \mathrm{~g} /$ day)

+ Percentage of subjects classified as chronic drinkers among those declaring more than

+ Percentage of subjects
$80 \mathrm{~g} /$ day $($ or $30 \mathrm{~g} /$ day $)$ drinking was frequent in fights (men $29 \%$, women $6 \%$ ) and in traffic accidents for men (15\%) but very rare in accidents occurring at work or at home. Subjects injured in fights and in domestic accidents were more often classified as chronic heavy drinkers, whatever the sex (table V). In addition, chronic drinkers were on average 10 years older than occasional drinkers or non-drinkers (42 years $v 32$ years, $\mathrm{p}<0.001$ in men; 49 years $v 39$ years, $\mathrm{p}<0.001$ in women). Among chronic drinkers the proportion of divorced subjects was significantly higher $(14 \% v 4 \%, \mathrm{p}<0.001$ in men; $26 \% v 14 \%$, $\mathrm{p}<0.001$ in women). Another striking result was that the percentage of unemployed people was at least twice as high in the groups of occasional drinkers as in the rest of the casualties $(14.5 \% v 6.8 \%, \mathrm{p}<0.001$ in men; $9.4 \%$ $v 4.5 \%$ in women, where the sizes of the groups were too small to reach statistical significance).

TABLE V-Comparison of non-drinkers, occasional drinkers, and chronic drinkers according to type of accident. Values are percentages and numbers

\begin{tabular}{lcccccc}
\hline $\begin{array}{c}\text { Type of drinkers } \\
\text { (and No of subjects) }\end{array}$ & Traffic & Work & Home & Sport & Fight \\
\hline $\begin{array}{l}\text { Men: } \\
\quad \text { Non-drinkers (2103) }\end{array}$ & $58(760)$ & $75(656)$ & $57(328)$ & $90(208)$ & $36(151)$ \\
$\begin{array}{l}\text { Occasional drinkers } \\
(390)\end{array}$ & $15(192)$ & $2(22)$ & $8(46)$ & 2 & $(4)$ & $29(124)$ \\
$\quad \begin{array}{c}\text { Chronic drinkers (934) } \\
\text { Women: }\end{array}$ & $27(361)$ & $23(203)$ & $35(206)$ & $8(18)$ & $35(145)$ \\
$\quad$ Non-drinkers (903) & $71(411)$ & $81(90)$ & $59(283)$ & $86(60)$ & $45(56)$ \\
$\begin{array}{l}\text { Occasional drinkers } \\
(32)\end{array}$ & $2(13)$ & $1(1)$ & $2(10)$ & 1 & $(1)$ & $6(7)$ \\
$\quad$ Chronic drinkers (434) & $27(154)$ & $18(20)$ & $39(190)$ & 13 & $(9)$ & $49(60)$ \\
\hline
\end{tabular}

\section{Discussion}

This study was designed to avoid the main bias generally encountered regarding the time and place of accidents. The sample taken was as large as possible and was taken in 21 centres from all parts of France to achieve representativeness. Nevertheless, it is impossible to assess its representativeness in the absence of reliable exhaustive statistics for all kinds of casualties. The possibility that some selection affected recruitment cannot be excluded since the subjects were admitted only to public hospitals with an emergency unit which had agreed to participate in the study. Obviously some accidents occurring far from the hospital centre or casualties admitted to private clinics were missed. This was more likely to happen for accidents at home or during sport, since the legal aspects of the other accidents generally led to police intervention and thus to the use of the public care system. Nevertheless, this possible bias could not explain the strong relations found between blood alcohol concentration and $\gamma$-glutamyltransferase activity or mean corpuscular volume, which provide the basis for our conclusions.

Another weakness of the study was the lack of a control group of non-injured subjects investigated in similar conditions (except for the accident itself) - that is, during driving, working, fighting, and so on. This was not even considered for obvious reasons of feasibility. Nevertheless, in a study that was performed in 1977 on 3040 non-injured drivers the blood alcohol concentration was more than $17 \cdot 4 \mathrm{mmol} / \mathrm{l}(0.8 \mathrm{~g} / \mathrm{l})$ in $4 \cdot 1 \%$ of men and $0.2 \%$ of women. ${ }^{17}$ The corresponding figures among the casualties from traffic accidents were $30.9 \%$ and $8.5 \%$, representing odds ratios equal to 10.4 in men and 46.4 in women. The original finding in our study lies in the very important proportion of chronic drinkers among the casualties, shown by, firstly, the high percentage of subjects with increased values of $\gamma$-glutamyltransferase or mean corpuscular volume, or both; secondly, the strong correlation coefficients of those markers with the blood alcohol concentration; and, thirdly, the results of the discriminant analysis. In addition, we analysed the differences between the various kinds of accidents.

The method of classification used, based on $\gamma$-glutamyltransferase and mean corpuscular volume values, was a substitute for the actual daily consumption of alcohol, which could not be obtained reliably under the conditions of the study. In fact, in relation to the true prevalence of heavy drinkers in the population, several subjects were misclassified because of the sensitivity and specificity of the particular test we used. For this reason we chose a specificity of $90 \%$ 
so that errors of classification were mainly due to false negative subjects. Thus the final proportions of chronic drinkers were probably underestimated. We must emphasise that the method used in this study is appropriate for describing a population, or comparing different groups, but is unreliable for assessing accurately the alcohol consumption of individuals.

The cut off points chosen to classify subjects as chronic heavy drinkers $(80 \mathrm{~g}$ of pure alcohol in men and $30 \mathrm{~g}$ in women) are also debatable. They do not correspond to the concept of a threshold in alcohol consumption but rather to the usual values considered in France. A similar analysis performed with other cut off points would also yield a greater prevalence of heavy drinkers among casualties. It is important to keep in mind the fact that the reliability of our results lies in the comparative approach adopted in this study. This approach was made possible by the systematic measurement of $\gamma$-glutamyltransferase activities (performed centrally) and mean corpuscular volume and the availability of epidemiological data previously collected in a healthy population.

Clearly these results do not allow us to conclude that alcohol consumption has a causal role in accidents. Among chronic drinkers it is not known whether abstinence contributes to greater vigilance or not. Nevertheless, the particularly high proportion of chronic drinkers found among drivers suggests that the parallelism between alcohol consumption and the incidence of fatal road accidents in France is probably not the effect of chance alone. Previous national campaigns for road safety have been directed at occasional drinkers. The low percentage of this kind of intoxicated driver indicates that a more thorough preventive policy must now address the major problem of chronic consumers of alcohol.

This work was supported by grants from the French Ministry of Health and Social Affairs (Direction of Health) and the Haut Comité d'Etude et
d'Information sur l'Alcoolisme. We thank E Garat-Lesieux and S CeneeProd'Homme for their technical assistance.

\section{References}

1 Kastrup $M$, Dupont A, Bille $M$, Lund $H$. Drunken drivers in Denmark. A nationwide epidemiological study of psychiatric patients, alcohol and traffic accidents. $\mathcal{I}$ Stud Alcohol 1983;44:47-56.

2 McDermott FT, Hughes ES. Compulsory blood alcohol testing of road crash casualties in Victoria: the second three years (1978-1980). Med f Aust 1982;i:294-6.

3 Vine J, Watson TR. Incidence of drug and alcohol intake in road traffic accident victims. Med $\mathcal{f}$ Aust 1983;i:612-5.

4 Woodward A. Motorcycle accidents in Nottinghamshire. Public Health 1983;97:139-48.

5 Blanc JL, Genot A, Lyoen M, Vignon H. Alcoholemia and traumatology in SAMU 42. Annales d'Anesthésiologie Françaises 1980;21:165-9.

6 Got C, Faverion G, Thomas C. Alcool et accidents mortels de la circulation. Bulletin du Haut Comité d'E tude et d'Information sur l'Alcoolisme 1984;1-2:38-60.

7 Murat J, Weill J, Lamy J, Leroy G. Incidence de l'alcoolisme sur la nature des lésions traumatiques des accidentés de la route. Annales de Médecine des Accidents et du Trafic. traumatiques 1980;26:14

8 Murat JE, Weill J. Alcoolisme et urgences chirurgicales. Lyon Chirurgical 1985;81:262-6.

9 Dunbar JA, Ogston SA, Ritchie A, Devgun MS, Hagart J, Martin BT. Are problem drinkers dangerous drivers? An investigation of arrest for drinking and driving, serum gamma-glutamyltranspeptidase activities, blood alcohol concentrations, and road traffic accidents: the Tayside Safe Driving Project. Br Med f 1985;290:827-30.

10 Haut Comité d'Etude et d'Information sur l'Alcoolisme. La consommation des boissons. Paris: La Documentation Française, 1984

11 INSERM. Statistiques des causes médicales des décès. Tome I. Résultats France. Paris: Editions INSERM, 1977:141-53.

12 Rosalki SB, Rau D. Serum gamma-glutamyl transpeptidase activity in alcoholism. Clin Chim Acta 1972;39:41-7.

13 Unger KW, Johnson DJ. Red blood cell mean corpuscular volume: a potential indicator of alcohol usage in a working population. Am F Med Sci 1974;267:281-9.

14 Papoz L, Warnet JM, Péquignot G, Eschwege E, Claude JR, Schwartz D. Alcohol consumption in a healthy population. FAMA 1981;245:1748-51.

15 Szasz G. A kinetic photometric method for serum gamma-glutamyl transpeptidase. Clin Chem 1979;15:124-36.

16 Institut National de la Statistique et des Etudes Economiques. Recensement général de la population de 1982. Paris: INSEE, 1984. (Collections de l'INSEE. Série D. 98).

17 Biecheler MB, Duval H, Filou C, Lassarre S, L'Hoste J. Alcool, conduite et insécurité routière. Cahiers d'Etudes de TONSER. 1985;65.

(Accepied 7 April 1986)

\section{SHORT REPORTS}

\section{Food allergy or intolerance in severe recurrent aphthous ulceration of the mouth}

Although the cause of oral aphthous ulcers is unknown, there is a well established association with coeliac disease.' Wray et al suggested recently that recurrent aphthous ulceration may in some cases be due to gluten sensitivity in the absence of coeliac disease, ${ }^{2}$ and other authors have suggested allergy to various foods, including figs, cheese, and tomatoes ${ }^{3}$ and walnuts, tomatoes, and fruit. ${ }^{4}$ We tested the hypothesis that chronic aphthous stomatitis may be due to food allergy or intolerance, taking as our three most likely dietary suspects gluten, cows' milk protein, and azo dyes and preservatives.

\section{Patients, methods, and results}

Fifteen patients ( 11 women), mean age 29 (range 16-76) years, entered the trial All had suffered severe oral aphthous ulcers most days for over a year and had normal serum vitamin $B_{12}$, folate, red cell folate, and serum iron concentrations. A detailed medical history and examination was performed to exclude inflam matory bowel disease and Behçet's syndrome.

For each patient serum immunoglobulin concentration was estimated and biopsy specimens taken from both the buccal mucosa, under local anaesthesia and the jejunum, using a Watson capsule. The small bowel biopsy specimen were examined histologically for coeliac disease, and mouth and intestinal biopsy specimens were screened by immunofluorescence techniques for local deposition of the immunoglobulin classes $\operatorname{IgA}, \operatorname{IgM}$, and $\operatorname{IgG}$ and also for the presence of $\mathrm{C} 3$.

Each dietary exclusion period lasted 10 weeks and was followed by 10 weeks return to normal diet. Patients were reviewed regularly by the doctor and dietitian. In the gluten free diet all sources of wheat, barley, rye, and oats were avoided; the milk free diet excluded all natural milk and milk products (soya milk as a substitute was allowed); the azo free diet excluded tartrazine (E102), sunset yellow (E110), new coccine (ponceau 4R; E124), and benzoic acid (E210).

A strict record was kept of the occurrence, duration, and frequency of ulcers. If a patient responded dramatically to the withdrawal of a specific food with relapse after returning to a normal diet the test was repeated and the response noted. Patients whose ulcers cleared on dietary restrictions were followed up on a long term basis and their progress recorded (table).

Patient details and results of dietary restriction

\begin{tabular}{|c|c|c|c|c|c|}
\hline $\begin{array}{l}\text { Case } \\
\text { No }\end{array}$ & $\begin{array}{c}\text { Age } \\
\text { (years) }\end{array}$ & Sex & $\begin{array}{l}\text { Duration of } \\
\text { disease } \\
\text { (years) }\end{array}$ & $\begin{array}{l}\text { Response to } \\
\text { food withdrawal }\end{array}$ & $\begin{array}{l}\text { Length of } \\
\text { follow up } \\
\text { (years) }\end{array}$ \\
\hline 1 & 20 & $\mathbf{F}$ & 5 & Cleared with gluten free diet & 3 \\
\hline 2 & 25 & $\mathbf{F}$ & 20 & Cleared with gluten free diet & 1 \\
\hline 3 & 23 & $\mathbf{F}$ & $>10$ & Cleared with gluten free diet & 4 \\
\hline 4 & 27 & $\mathbf{F}$ & 23 & Cleared with azo free diet & 2 \\
\hline 5 & 27 & $\mathbf{F}$ & 5 & Cleared with azo free diet & $1 \cdot 25$ \\
\hline 6 & 60 & $\mathbf{M}$ & 12 & Cleared with milk free diet & 2 \\
\hline 7 & 73 & $\mathbf{F}$ & 12 & $\begin{array}{l}\text { Some improvement with milk and } \\
\text { azo free diet }\end{array}$ & \\
\hline 8 & 16 & $\mathrm{~F}$ & 14 & No response & \\
\hline 9 & 13 & $\mathbf{M}$ & 2 & $\begin{array}{l}\text { Some improvement with milk free } \\
\text { diet }\end{array}$ & \\
\hline 10 & 35 & $\mathrm{~F}$ & 8 & No response & \\
\hline 11 & 15 & $\mathbf{M}$ & 2 & $\begin{array}{l}\text { Improvement with azo free diet } \\
\text { then spontaneous remission }\end{array}$ & \\
\hline 12 & 30 & $\mathbf{F}$ & 1 & $\begin{array}{l}\text { Cleared spontaneously before test } \\
\text { diets (? stress related) }\end{array}$ & \\
\hline 13 & 20 & $\mathbf{M}$ & 10 & Patient defaulted after inclusion & \\
\hline 14 & 20 & $\mathrm{~F}$ & 10 & Patient defaulted after inclusion & \\
\hline 15 & 24 & $\mathbf{M}$ & 2 & Patient defaulted after inclusion & \\
\hline
\end{tabular}

*During prolonged period of follow up patients tended to experiment with diets. Some found During prolonged period of follow up patients tended to experiment with diets. Some found quantity of suspect food mattered; others found they could induce remissions that would last
for some months with normal diet but eventually relapsed and had to return to dietary restrictions, when ulcers again cleared.

No patient had villous atrophy on intestinal biopsy examination, thus excluding coeliac disease. No significant abnormality was found in the results of serum immunoglobulin assays, and there was no increase in the deposition of immunoglobulins in the buccal or intestinal mucosal samples, apart from some IgA, which would be expected in the gastrointestinal tract.

In five patients there was an unexpected finding on routine histological 